\title{
Study on Knowledge Collaboration Innovation of College Counselors
}

\author{
Shiyong Lu, Yuan Zhang
}

Shandong University, Jinan Shandong, 250101, China

Key words: Counselor, Knowledge collaboration, Innovation.

\begin{abstract}
The progress of current science and technology and the emergence of network technology allow colleges and universities to have new understandings of knowledge collaboration innovation of college counselors. This paper explores the process of knowledge collaboration innovation of college counselors and its action mechanism on this basis according to post characteristics of college counselors, meanwhile introduces organizational learning and life-long learning theories, puts forward a model of knowledge collaboration innovation of college counselors and conducts first exploration on it.
\end{abstract}

\section{Study background}

The Ministry of Education proposed to set up ideological and political counselors in colleges and universities in 1952.The team of college counselors has gradually strengthened so far. Requirements for comprehensive quality of counselors become increasingly higher. It is extremely urgent to professionalize college counselors. As persons with the closest relationship with college students in colleges and universities, counselors play a vital role. On the one hand, they are the guide of college students in ideology and politics, who help college students to establish positive world outlook, outlook on life and value and provide reasonable counseling for college students in ideological and political problems in learning, life and work in time. On the other hand, they are the most approachable and closest person for college students in their college life, who can communicate with college students, manage and standardize their words and deeds effectively and exclude the difficulty and anxiety of college students.

With the rapid development of current economic society and constant prominence of personality of contemporary college students, colleges and universities have increasingly higher requirements for knowledge reserve and application ability of counselors which can no longer be met alone with personal learning and further education of counselors.

Core competitiveness can be improved and even created through collaboration. Knowledge collaboration put forward in this paper refers to the process in which an organization realizes "2+2>4" with measures such as knowledge resource sharing and united or unified implementation of knowledge training on the basis of consistent overall objectives and concept. Its specific contents not only include the process of knowledge resource acquisition, sharing, innovation and application by the organization as well as knowledge exchange and transfer occurring in this process, but also are manifested in auxiliary activities of the organization such as infrastructure support, reward and punishment mechanism and cultural development in terms of knowledge collaboration. On the one hand, the realization of knowledge collaboration of counselors in colleges and universities can realize inter-organizational knowledge sharing and enlargement, produce "joint effect", promote the formation of new knowledge resources and realize win-win situation. On the other hand, it is more conducive to the construction and management of counselor team by colleges and universities. It is undeniable that the management work of an organization will get double the result if it has unified knowledge value. Network structure of knowledge collaboration of college counselors is established with traditional knowledge acquisition way of personal acquisition broken through, as shown in 
fig.1.Knowledge acquisition platform (knowledge base) established by colleges and universities for counselors is in the center of network structure, which has the function of processing and sharing knowledge resource information passed and summarized. Each counselor is the creator and appropriator of knowledge resource who can use resources at any time. Meanwhile, counselors in the network can conduct effective cooperation and exchange, thus promoting reasonable flow and utilization of knowledge resources and realizing efficient flow and strong integration of knowledge.

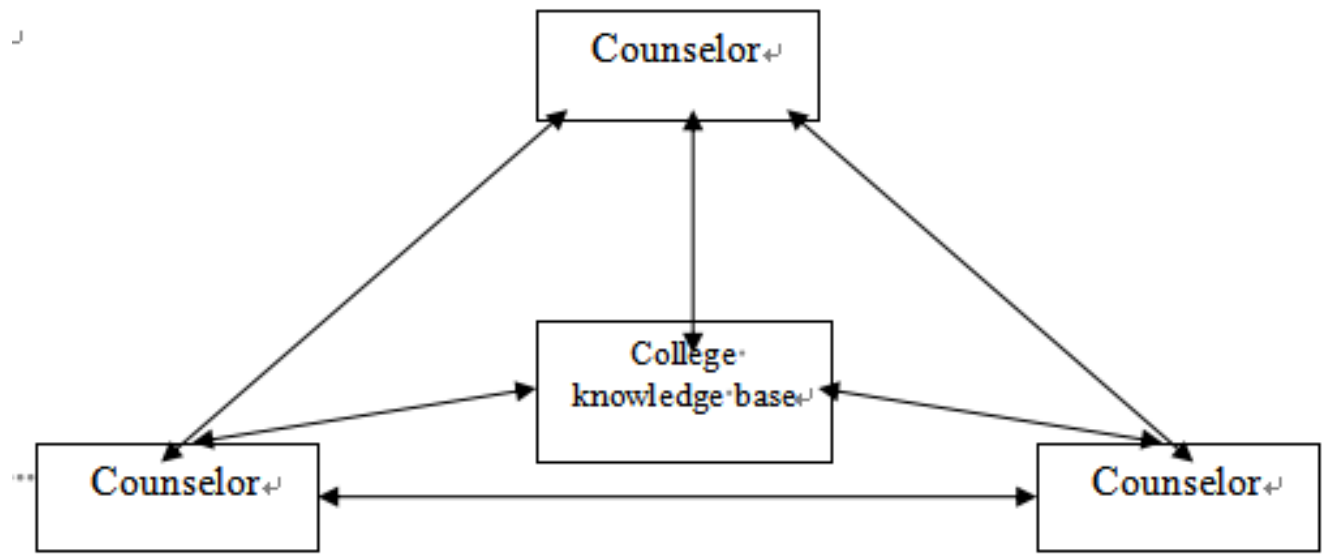

Fig. 1. Schematic Diagram of Counselors’ Knowledge Collaboration Network Architecture

\section{Knowledge collaboration innovation process of college counselors}

Due to the particularity of college environment and job nature of counselors, it seems especially important to discuss and study knowledge collaboration management of college counselors especially such issues as knowledge collaboration process and influence factors in order to realize existing knowledge collaboration effect and performance. This paper puts forward a model of knowledge collaboration innovation process of college counselors tentatively as shown in fig. 2 on the basis of considering previous research achievements and management theory comprehensively.

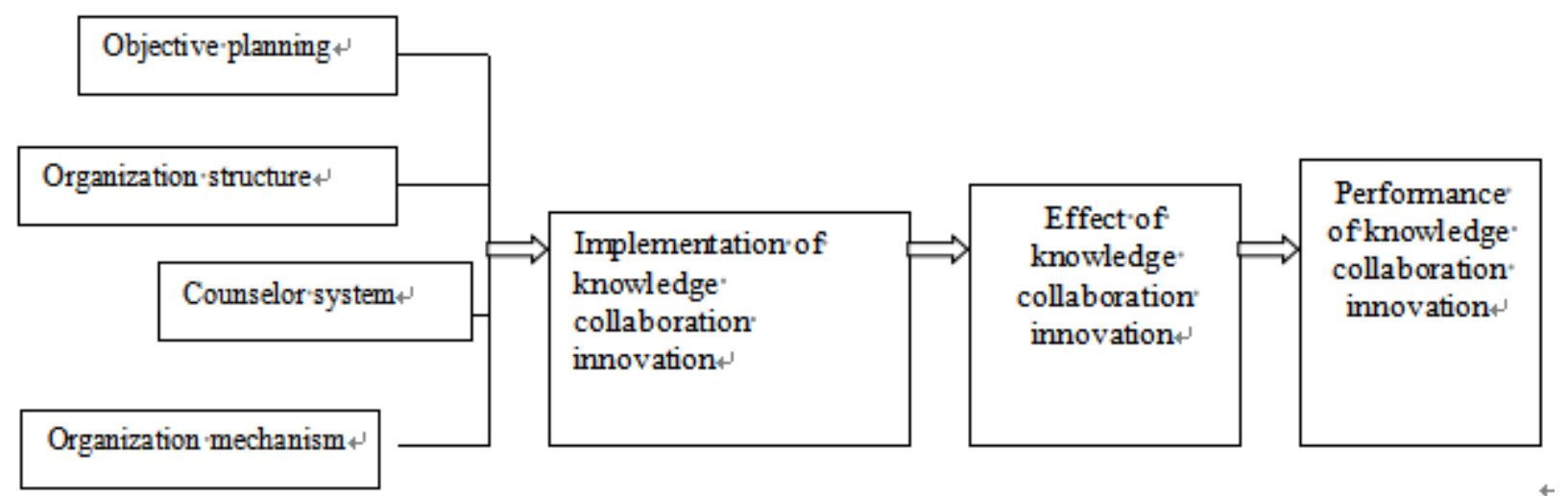

Fig. 2. Knowledge Collaboration Innovation Process Model of College Counselors

This paper finds that knowledge collaboration of college counselors has direct or indirect relation with objective planning (including overall running objectives of colleges and individual planning objectives), construction of organization structure, counselor management system and organizational management mechanism of teaching and administrative staff in colleges according to the practical situation in current college management through a summary of previous relevant theories. Therefore, this paper regard the factors mentioned above as main supporting conditions of knowledge collaboration innovation of college counselors which influence the process of their knowledge collaboration innovation. Successful knowledge collaboration innovation of counselors shall be 
conducted in colleges and universities so as to produce collaboration innovation effect. Meanwhile, innovation effect shall have positive correlation with internal innovation performance in colleges and universities.

\section{Knowledge collaboration innovation mechanism of college counselors \\ Objective planning}

Objective is defined as the achievement expected by individuals, departments or the whole organization. The difference of objective often causes difference action and disorder of each functional department inside the organization in the process of work and activities as well as unsmooth coordination and low efficiency. According to features of work environment of college counselors and knowledge collaboration process, this paper divides objective planning into overall running objective of colleges and individual planning objective. Table 1 shows their relation with knowledge collaboration innovation.

Table 1. Descriptions of Influence Factor Indicator System of Objective Planning

\begin{tabular}{|c|c|}
\hline Indicators & Relation \\
\hline $\begin{array}{c}\text { Overall objectives of } \\
\text { colleges }\end{array}$ & Degree of emphasis on knowledge collaboration innovation of counselors \\
put by colleges
\end{tabular}

\section{Organization structure}

Organization structure will influence collaborative innovation performance], including collaborative innovation of knowledge resources. The adjustment and optimization of organization structure is an important way to achieve collaboration. Therefore, organization structure is closely related to the realization of collaboration innovation and synergistic effect. Table 2 shows influence factors of organization structure for knowledge collaboration.

Table 2. Descriptions of Influence Factor Indicator System of Organization Structure

\begin{tabular}{|c|c|}
\hline Indicators & Indicator description \\
\hline \multirow{3}{*}{$\begin{array}{c}\text { Organization } \\
\text { structure }\end{array}$} & $\begin{array}{c}\text { Flat organization structure is more conducive to the transmission and sharing of } \\
\text { knowledge resources. }\end{array}$ \\
\cline { 2 - 2 } & $\begin{array}{c}\text { Flexible organization structure is more conducive to the innovation of knowledge } \\
\text { resources. }\end{array}$ \\
\cline { 2 - 2 } & $\begin{array}{c}\text { Closer geographic position makes it easier to form consistent culture, thus } \\
\text { facilitating knowledge collaboration and innovation. }\end{array}$ \\
\hline
\end{tabular}

\section{Counselor system}

Members in the organization are the most important resources in the system. As grass-roots workers in colleges, counselors play a role as bridge connecting colleges and students.Overseas studies have found that main reasons for incoordination among functional departments are different values of members in the organization as well as asymmetric information and unsmooth communication among functional departments.Meanwhile, work and collaboration innovation activities of counselors are inseparable from the support and participation of superior leadership. Senior leaders in the organization play an important role in promoting collaboration innovation. Table 3 shows influence indicators of counselor system. 
Table 3. Descriptions of Indicator System of Influence Factors of Counselor System

\begin{tabular}{|c|c|}
\hline Indicators & Indicator description \\
\hline \multirow{3}{*}{ Counselor system } & $\begin{array}{c}\text { Degree of emphasis on and participation in knowledge collaboration innovation by } \\
\text { senior managers in counselor system }\end{array}$ \\
\cline { 2 - 3 } & $\begin{array}{c}\text { Rich experience and strong coordination ability of counselors make it easier to conduct } \\
\text { knowledge collaboration innovation. }\end{array}$ \\
\cline { 2 - 3 } & $\begin{array}{c}\text { Higher similarity of knowledge level (education) of counselors is more conducive to } \\
\text { knowledge collaboration innovation. }\end{array}$ \\
\hline
\end{tabular}

\section{Organization mechanism}

Organization mechanism put forward in this paper mainly involves two aspects - incentive mechanism and coordination mechanism. Reasonable and fair incentive mechanism improves the motivation of each functional department and counselors in colleges for participating in knowledge collaboration innovation. Coordination mechanism will directly influence the effect of knowledge collaboration innovation between each functional department and counselor in colleges and universities. Table 4 shows its indicator descriptions.

Table 4. Descriptions of Influence Factor Indicator System of Organization Mechanism

\begin{tabular}{|c|c|}
\hline Indicators & Indicator description \\
\hline $\begin{array}{c}\text { Organization } \\
\text { mechanism }\end{array}$ & $\begin{array}{c}\text { Incentive mechanism improves the motivation of knowledge collaboration } \\
\text { innovation. }\end{array}$ \\
\cline { 2 - 2 } & Coordination mechanism directly influences the effect of knowledge \\
collaboration innovation.
\end{tabular}

Meanwhile, increasing formal and informal communication among members in the organization or carrying out some collective activities such as celebration and party in good time can promote collaboration. 


\section{Knowledge collaboration innovation model of college counselors}

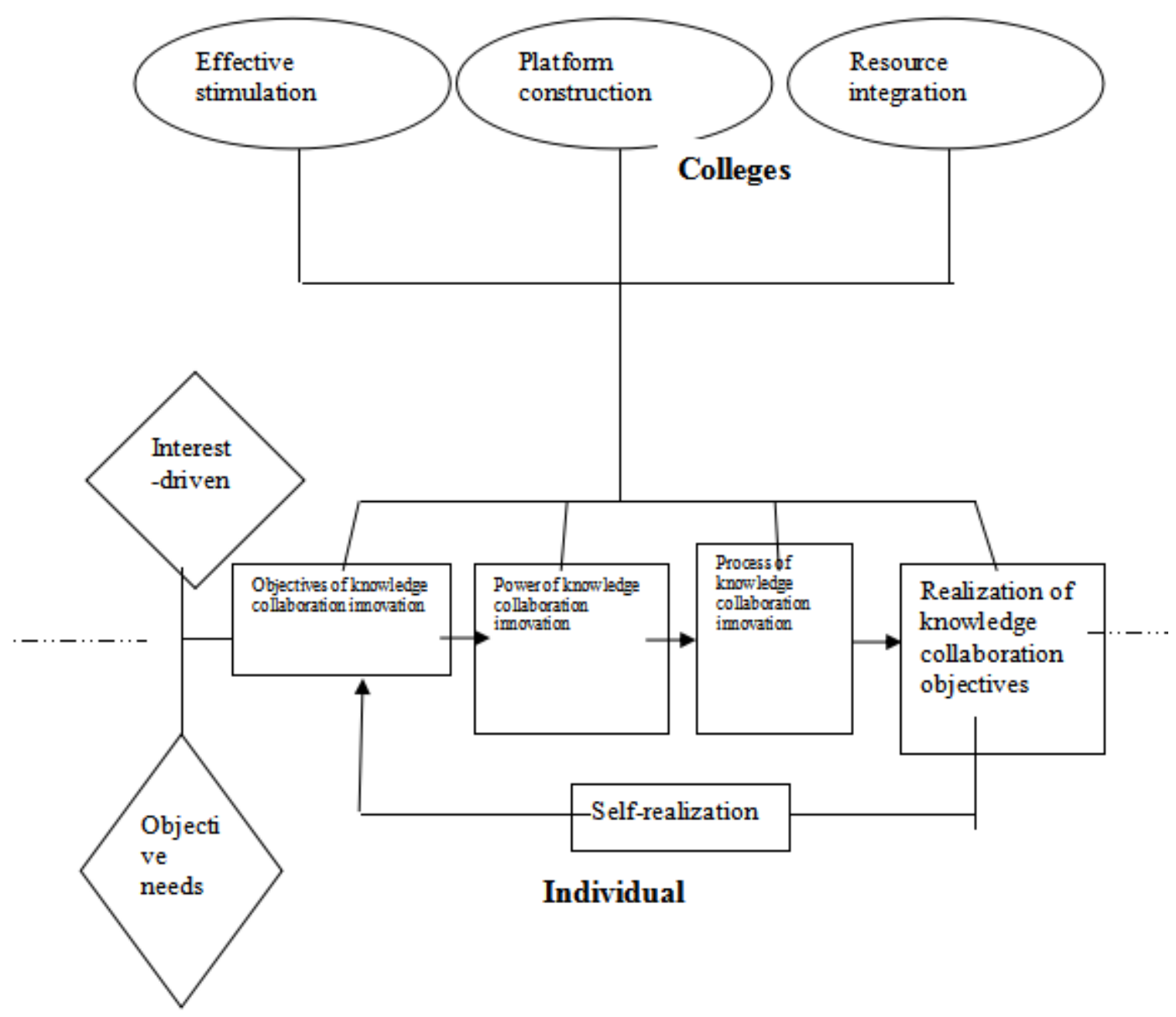

Fig. 3. Knowledge collaboration innovation model of college counselors

This study puts forward knowledge collaboration innovation model of college counselors as shown in fig. 3 based on literature review and preliminary study according to work features and environment of college counselors in combination with exploration in operating post of counselors and the introduction of organizational learning theory and life-long learning theory.

Objective demands of college counselors for knowledge collaboration innovation mainly come from internal and external factors. External factors mainly refer to environmental requirement, e.g. constantly increasing demands of counselors for knowledge resources brought by social development and knowledge economy. Internal factors mainly come from individual interest and the demand for improving internal capacity. Driven by objective demand, counselors acquire and share knowledge resources through collaboration and realize self-transcendence and self-objectives based on certain external supporting conditions (incentive and restraint mechanism, platform construction and effective resource integration system established by colleges and universities for knowledge collaboration innovation work). Such success will in turn stimulate counselors for knowledge resource collaboration innovation in college system and new learning and improvement, thus forming a benign cycle operation system. Such knowledge collaboration way cannot be accomplished in an action. It advances constantly with progressive, tortuous and periodic trend and presents a spiral form of motion, thus impelling individuals to advance towards a higher level constantly. 
Today with increasingly rapid development of knowledge-based economy society, college counselor system should consider how colleges and counselors can acquire and apply knowledge resources timely and effectively and further improve their comprehensive quality so as to cope with social development changes positively. The model and practice of knowledge collaboration innovation of college counselors put forward in this paper will meet many problems in the specific implementation process, such as the establishment of collaboration platform, limited funds and manpower and difficulty in improving reasonable incentive mechanism. This requires colleges and counselors to make more studies and attempts in the future work based on the reality.

\section{References}

[1] Ansoff H. I. Corporate Strategy: An Analytic Approach to Business Policy for Growth and Expansion, New York: McGraw-Hill, 1965.

[2] Ansoff I. 1965. Corporate Strategy. New York: Mc-Graw-Hill.

[3] Cooper R G. 1984. The Performance Impact of Product Innovation Strategies, European Journal of Marketing, 8(5).

[4] Ranjay Gulati. 1998. Alliance and Networks, Strategic Management Journal, 19(4).

[5] Wang Chen, Zhao Yingjun, Liu Tao. Synergistic Effect and Its Access Way and Approach, Academic Exchange, 2004(10).

[6] Bailey E P. 1999. Writing \& Speaking at Work, New Jersey: Prentice Hall, Inc.

[7] Chen Yansong. Role Definition and Knowledge Structure Development of College Counselors, Higher Education of Jiangsu, 2009(4).

[8] Zhang Ailin, Zhou Yafu. Knowledge Structure of College Counselor and Its Optimization, Studies in Ideological Education, 2011(6).

[9] Yang Yanling. First Exploration on Practical Knowledge of College Counselors, Journal of National Academy of Education Administration, 2010(11). 